\title{
PENGARUH VARIASI TEKANAN PADA PEMBAKARAN SPRAY BAHAN BAKAR MINYAK KELAPA MURNI TERHADAP SUDUT, PANJANG NYALA API, DIAMETER DROPLET, FLASHBACK
}

\author{
Irwan Tri Murdianto \\ Teknik Mesin, Fakultas Teknik \\ Universitas Maarif Hasyim Latif, Sidoarjo, Indonesia \\ e-mail : irwan-tri-murdianto@student.umaha.ac.id
}

\begin{abstract}
ABSTRAK
Ditengah tingginya kebutuhan bahan bakar fosil membuat ketersediannya menipis, Berbagai penelitian tentang minyak nabati dilakukan untuk mencari bahan bakar alternatif lain mengurangi pemakaian bahan bakar fosil Sumber minyak nabati yang mudah diperoleh ialah minyak kelapa murni Pohon kelapa telah banyak tersebar Dalam penelitian ini menggunakan metode eksperimental pembakaran spray bahan bakar yang dipakai minyak kelapa murni dengan memvariasikan tekanan 50 bar 75 bar dan 100 bar serta diameter nozzle $0,2 \mathrm{~mm}$ bertipe spray solid cone proses pengujian dilakukan secara berulang ulang hingga mendapat data yang maksimal dari uji eksperimental ini didapat bahwa tekanan bisa mempengaruhi besar kecil sudut spray panjang nyala api diameter droplet flashback nyala api hasil pengujian ini diketahui semakin tinggi tekanan maka sudut akan besar sebaliknya tekanan rendah membuat sudut akan mengecil panjang nyala api bertambah panjang ketika tekanan semakin tinggi terjadinya flashback pada penyalaan awal jarak $100 \mathrm{~mm}$ dan $500 \mathrm{~mm}$ diameter droplet akan bertambah kecil saat tekanan semakin tinggi
\end{abstract}

Kata kunci : droplet, nyala api, minyak kelapa, pembakaran spray, sudut, tekanan

\section{PENDAHULUAN}

Kebutuhan energi terus meningkat seiring semakin majunya teknologi dan bertambahnya jumlah penduduk didunia. Penggunaan bahan bakar minyak fosil yang terus meningkat ini mengakibatkan cadangan semakin menipis. Para peneliti berusaha mencari energi yang baru, seperti minyak nabati termasuk energi terbarukan. Pohon Kelapa merupakan tanaman yang tersebar di indonesia serta banyak tumbuh di dataran tinggi maupun rendah. Buah kelapa bisa diolah menjadi minyak kelapa dengan beberapa proses yakni secara pemanasan dan pengepresan.

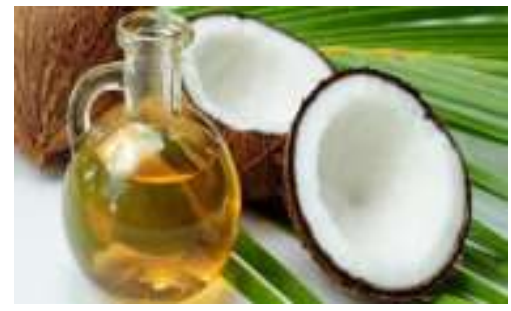

Gambar 1. Minyak kelapa

Minyak kelapa murni memiliki Kandungan asam lemak rantai cukup panjang serta asam lemak jenuh yang tinggi sebesar $90 \%$, asam lemak jenuh banyak di dominasi asam laurat yang berantai. Serta Bahan bakar minyak kelapa murni tersusun dari beberapa molekul triglyceride terdiri dari glycerol yaitu alkohol yang berjumlah tiga rantai karbon sebagai rantai utama dan tiga cabang asam lemak dengan rantai berjumlah 18 karbon atau 16 karbon.

Tabel 1. Kandungan asam lemak minyak kelapa

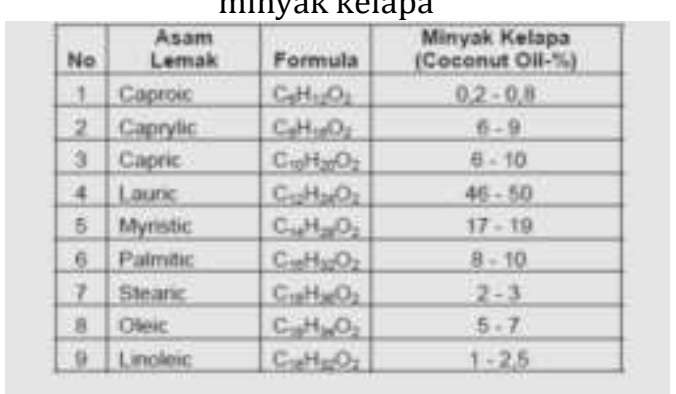

Pada tabel 1 diatas memperlihatkan kandungan minyak kelapa murni. Minyak kelapa salah satu minyak nabati yang bisa digunakan dalam pembakaran spray. Kandungan asam lemak yang cukup tinggi membuat berbeda dibandingankan dengan jenis minyak nabati yang lain, dan tinggi viscositas cukup tinggi. Setiap minyak nabati terdapat sifat - sifat fisik yang berbeda, tabel 2 di bawah ini menunjukkan sifat fisik pada minyak nabati terutama minyak kelapa murni.

Tabel 2. Sifat fisik minyak nabati murni 


\begin{tabular}{|c|c|c|c|c|c|c|c|c|}
\hline Property & $\begin{array}{l}\text { ASTM } \\
\text { methode }\end{array}$ & Instrument & Nodel & $\begin{array}{c}\text { Valua } \\
\text { Ceiba } \\
\text { peanda } \\
\text { dil }\end{array}$ & $\begin{array}{l}\text { Jatropha } \\
\text { curcas } \\
\text { lin } \\
\text { Oil }\end{array}$ & $\begin{array}{l}\text { Catton } \\
\text { seed } \\
\text { oil }\end{array}$ & $\begin{array}{c}\text { Coconit } \\
\text { oil }\end{array}$ & $\begin{array}{c}\text { Palm } \\
\text { kemel } \\
\text { dil }\end{array}$ \\
\hline $\begin{array}{l}\text { Density at } \\
40^{\circ} \mathrm{C} \\
\left(\mathrm{kggm}^{3}\right)\end{array}$ & D1298 & Hydrometer & $\begin{array}{l}\text { Nikfyy, } \\
\text { Japan }\end{array}$ & 974 & 921 & 955 & 936 & 940 \\
\hline $\begin{array}{l}\text { Kinematic } \\
\text { vizcosity } \\
\text { at } 40^{\circ} \mathrm{C} \\
(\mathrm{CSt})\end{array}$ & $D 445$ & $\begin{array}{l}\text { Kinematic } \\
\text { visconeter }\end{array}$ & $\begin{array}{l}\text { Leybold } \\
\text { Didectic, } \\
\text { Gemany }\end{array}$ & 45,55 & 35,48 & 4165 & 55,55 & 5265 \\
\hline $\begin{array}{l}\text { Flash } \\
\text { point ( (C) }\end{array}$ & D99 & $\begin{array}{l}\text { Pensiy: } \\
\text { Martens } \\
\text { dosed } \\
\text { cup tester }\end{array}$ & $\begin{array}{l}\text { Leybold } \\
\text { Didectic, } \\
\text { Gemany }\end{array}$ & 260 & 240 & 250 & 265 & 270 \\
\hline $\mathrm{pH}$ & D6423 & pHep tester & $\begin{array}{c}\text { UAS } \\
\text { HANNA } \\
\text { Instrugent } \\
\text { UAS }\end{array}$ & 5,0 & 4.5 & 40 & 6,0 & 6.0 \\
\hline
\end{tabular}

Menurut pengaertian Pembakaran spray ialah proses pembakaran dimana bahan bakar yang masih berupa cairan diubah ke fase pengabutan atau berbentuk butiran - butiran droplet yang bertujuan bahan bakar tersebut terbakar dengan sempuran. Proses tersebut terjadi tiga tahapan yakni lembaran tipis (sheet) akan membentuk ikatan (ligament) dan kemudian pecah menjadi butiran (droplet). Apabila memiliki ukuran yang sangat kecil dan halus droplet tersebut bisa dikatakan bagus dan mempengaruhi efek yang signifikan pada proses pembakaran spray.

Proses pembakaran spray dipengaruhi oleh seberapa besar tekanan dan diameter lubang nozzle. Kombinasi dari spray bertekanan tinggi dapat menghasilkan ukuran droplet yang kecil, mempercepat penguapan dan meningkatkan proses atomisasi hingga membuat pembakaran bahan bakar lebih baik. Penelitian ini tentang pembakaran spray menggunakan minyak kelapa murni pada kali ini ingin mengetahui besar sudut spray, diameter droplet, panjang nyala api, dan flashback nyala api.

\section{METODE PENELITIAN}

Perencanaan penelitian merupakan proses awal kegiatan untuk mendapatkan hasil yang sesuai diinginkan, setelah perencanaan awal selesai maka pelaksanaan penelitian bisa dilakukan. Penelitian ini dimulai dari studi literatur yaitu mempelajari jurnal penelitian sebelumnya tentang pembakaran spray serta melakukan observasi alat yang akan digunakan sebagai penelitian maupun eksperimen kemudian melakukan persiapan alat dan bahan yang dibutuhkan, setelah itu proses perakitan alat uji, selanjutnya pengujian alat apabila masih terdapat kesalahan maka dilakukan proses pengujian ulang sampai mendapat data yang relevan, setelah pengujian berhasil bisa dilakukan proses pengambilan data kemudian dianalisa hasil data penelitian tersebut dan penyusunan laporan bisa dilakukan. Adapun instalasi pembakaran spray pada gambar 1 sebagai berikut :

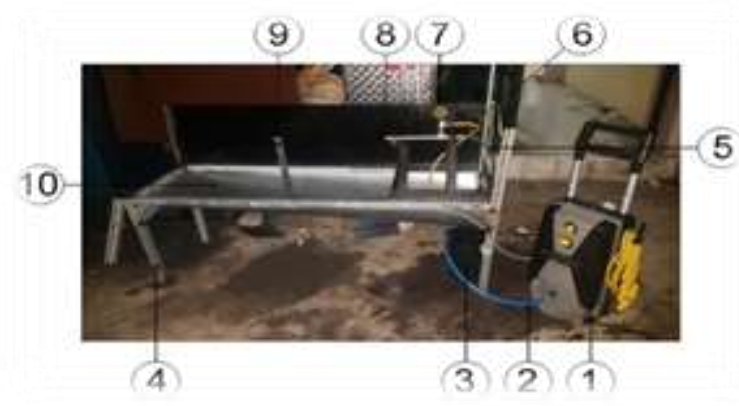

Gambar 2. Instalasi pembakaran spray Alat dan Bahan

Alat :

1. Pompa Jet Cleaner High Pressure 150 Bar

2. Selang

3. Ember penampung minyak

4. Meja pengujian

5. Selang tekanan tinggi

6. Selang by pass valve

7. Pressure gauge

8. Nozzle

9. Penggaris besi

10. Wadah penampung minyak

Bahan :

Minyak kelapa murni

Tempat dan waktu kegiatan

a. Persiapan bahan baku Minyak kelapa murni dibeli di online shop (toko minyak kelapa murni SHOPEE).

b. Penelitian ini dilakukan di Di laboratorium Teknik Mesin Universitas Ma'arif Hasyim Latif. alamat di JL. Raya Ngelom Megare No 30 Megare, Taman, Sidoarjo, Jawa Timur.

Pengujian alat pembakaran spray ini menggunakan jenis minyak kelapa murni. Pengujian dilakukan dengan cara memvariasikan tekanan pada pompa jet cleaner yaitu sebesar 50 bar, 75 bar, dan 100 bar, serta menggunakan diameter lubang nozzle 0,2 mm. Data yang ingin diperoleh pada pengujian ini meliputi sudut spray, diameter droplet, panjang nyala api dan flashback nyala api. Langkah pengambilan data sudut spray bahan bakar minyak kelapa murni disemprotkan bertekanan tinggi dari pompa dan dialirkan ke nozzel melewati selang. Kemudian 
minyak kelapa keluar berbentuk kabut melalui nozzel hingga membentuk sudut. untuk panjang nyala api langkah pengambilan data seperti sudut spray namun diperlukan pemantik api agar diketahui panjang nyala api tersebut. Kemudian pengambilan flashback nyala api dilakukan dengan 3 kali penyalaan pada 3 jarak masing masing yaitu $100 \mathrm{~mm}, 500 \mathrm{~mm}, 900 \mathrm{~mm}$ dari ujung nozzel, Pengamatan rambatan api atau flashback direkam menggunakan kamera.

Proses pengambilan data ini direkaman menggunakan kamera cannon 1100D, untuk proses pengolahan data menggunakan software free video to JPG converter, image $j$, dan software corel draw $x 7$.

\section{HASIL DAN PEMBAHASAN}

Berikut merupakan Analisa dari hasil pengujiian spray dengan menggunakan bahan bakar minyak kelapa murni. Pada gambar 2 ialah pengujian secara actual pada sudut spray dengan diameter lubang nozzle 0,2 $\mathrm{mm}$ dan variasi tekanan yang digunakan 50 bar, 75 bar, 100 bar.

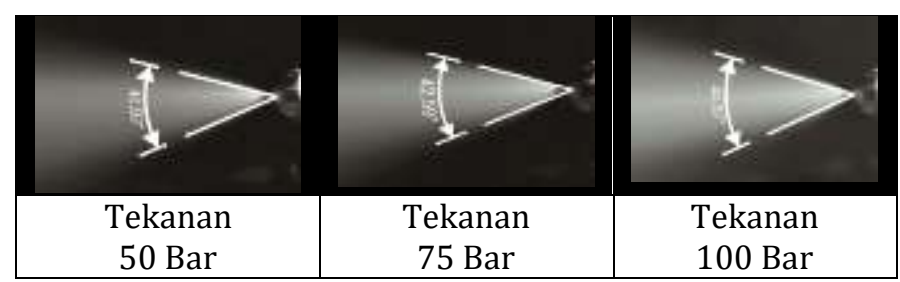

Gambar 3. Sudut spray pada masing masing pengujian

Tabel 3. Hasil olah data pengujian sudut spray

\begin{tabular}{|l|l|l|l|l|c|}
\hline No & $\begin{array}{l}\text { Nosel } \\
\text { (mm) }\end{array}$ & $\begin{array}{l}\text { Telanan } \\
\text { (Bar) }\end{array}$ & $\begin{array}{l}\text { Sudut } \\
\text { akt [] }\end{array}$ & $\begin{array}{l}\text { Sudut } \\
\text { teo [] }\end{array}$ & $\begin{array}{c}\text { Ker } \\
\text { Sempr[m/S] }\end{array}$ \\
\hline 1 & 0,2 & 50 & 40,92 & 39,04 & 70,24 \\
\hline 2 & 0,2 & 75 & 42,59 & 41,89 & 86,02 \\
\hline 3 & 0,2 & 100 & 44,67 & 43,94 & 99,34 \\
\hline
\end{tabular}

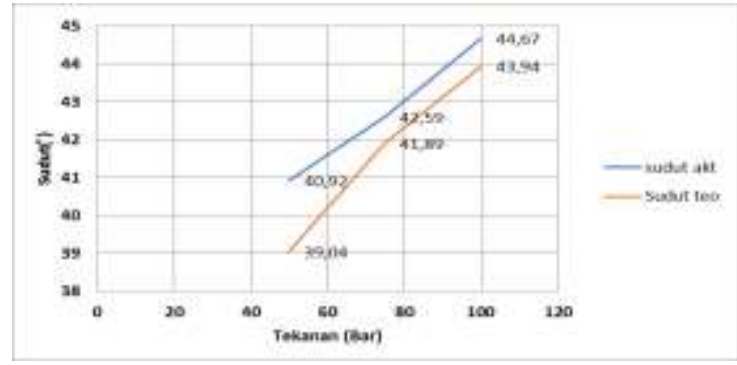

Gambar 4. Grafik perbandingan sudut spray variasi tekanan

Pada tabel 3 diketahui nilai kecepatan semprotan yang terjadi pada tekanan sebesar 50 bar yaitu $70,24 \mathrm{~m} / \mathrm{s}$ sedangkan nilai kecepatan semprotan paling tinggi yaitu 99,34 m/s pada tekanan 100 bar. Kecepatan semburan bahan bakar dapat diperkirakan secara teoritis menggunakan rumus persamaan sebagai berikut (Liguang, 2007).

$$
v_{i}=C_{d} \sqrt{\frac{2 \Delta p_{i}}{\rho_{l}}}
$$

Dimana:

$$
\begin{aligned}
& C_{d}=0,68 \text { (asumsi) } \\
& \rho_{l}=936 \mathrm{~kg} / \mathrm{m}^{3} \\
& \Delta p_{i} 1=50 \mathrm{bar}=5 \times 10^{6} \mathrm{~kg} / \mathrm{ms}^{2}
\end{aligned}
$$

Maka perhitungan kecepatan semprotan bahan bakar ialah :

$$
\begin{aligned}
& v_{i}=C_{d} \sqrt{\frac{2 \Delta p_{i}}{\rho_{l}}} \\
& =0,68 \sqrt{\frac{2 \times 5 \times 10^{6} \mathrm{~kg} / \mathrm{ms}^{2}}{936 \mathrm{~kg} / \mathrm{m}^{3}}}=70,24 \mathrm{~m} / \mathrm{s}
\end{aligned}
$$

Sedangkan secara teoritis, besarnya sudut spray ini juga dapat diperkirakan dengan menggunakan persamaan pada berikut (Borman, 1998).

$$
\theta_{1}=0,05\left(\frac{\Delta p i \cdot d^{2}}{\rho l \cdot \mu v}\right)^{1 / 4}
$$

Dimana

$$
\begin{array}{cl}
\Delta p_{i}=50 \mathrm{bar} & =5 \times 10^{6} \mathrm{~kg} / \mathrm{ms}^{2} \\
\mathrm{~d}^{2} & =0,2 \mathrm{~mm} \\
\rho_{l}(\text { densitas }) & =936 \mathrm{~kg} / \mathrm{m}^{3} \\
\mu v \text { (viscositas) } & =55,7 \mathrm{~mm}^{2} / \mathrm{s}
\end{array}
$$


Sehingga

$$
\begin{aligned}
& \theta_{1}=0,05 \\
& \left(\frac{5 \cdot 10^{6} \mathrm{~kg} / \mathrm{ms}^{2} \cdot(0,2 \mathrm{~mm})^{2}}{936 \mathrm{~kg} / \mathrm{m}^{3} \cdot\left(55,55 \mathrm{~mm}^{2} / \mathrm{s}\right)^{2}}\right)^{1 / 4} \\
& \quad=39,04^{\circ}
\end{aligned}
$$

Nilai ini sedikit lebih kecil dari nilai sudut secara actual pada pengujian sudut spray dengan minyak kelapa murni, nilai sudut spray pada tekanan 50 yang didapat secara actual yakni $40,92^{\circ}$. Hal tersebut bisa terjadi karena dipengaruhi oleh tegangan permukaan minyak nabati saat melewati lubang nozzel. Semakin besar tekanannya dapat menurunkan tegangan permukaan minyak yang melewati lubang nozzel tersebut.

Pada tabel 4 berikut merupakan hasil perhitungan secara teoritis diameter droplet pada masing - masing tekanan 50 bar, 75 bar dan 100 bar.

Tabel 4. Diameter droplet terhadap variasi tekanan

\begin{tabular}{|c|c|c|c|}
\hline No & $\begin{array}{c}\text { Tekanan } \\
(\text { bar })\end{array}$ & $\begin{array}{c}\text { Nozzel } \\
(\mathrm{mm})\end{array}$ & $\begin{array}{c}\text { Droplet } \\
(\mu \mathrm{m})\end{array}$ \\
\hline 1 & 50 & 0,2 & 16,8 \\
\hline 2 & 75 & 0,2 & 12,7 \\
\hline 3 & 100 & 0,2 & 10 \\
\hline
\end{tabular}

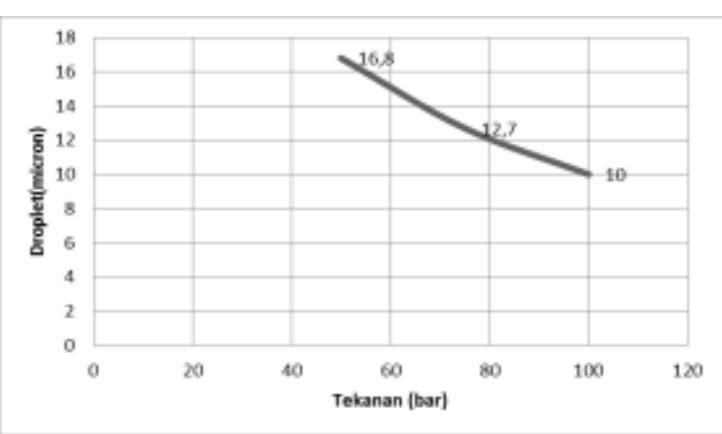

Gambar 5. Grafik diameter droplet terhadap variasi tekanan

Pada tabel 4 diatas diketahui diameter droplet terkecil pada minyak kelapa terjadi di tekanan sebesar 100 bar yaitu $10 \mu \mathrm{m}$, sedangkan diameter droplet terbesar terdapat pada tekanan 50 bar yaitu $16,8 \mu \mathrm{m}$. Hal ini memperlihatkan bahwa tekanan bisa mempengaruhi ukuran diameter droplet. Selain itu viskositas minyak kelapa juga berperan pada diameter droplet tersebut, semakin rendah nilai vikositas maka tingkat kekentalan minyak tersebut rendah. Untuk menghitung nilai diameter droplet menggunakan persamaan Sauter Mean Diameter (SMD) berikut (Viriatoet al,1996)

$$
\mathrm{D}_{32}=4.12 \mathrm{~d}_{\mathrm{n}} R e^{0,12} W e^{-0,75}\left\{\frac{\mu_{f}}{\mu_{a}}\right\}^{0,54}\left\{\frac{\rho_{f}}{\rho_{a}}\right\}^{0,18}
$$

Agar persamaan diatas bisa ditentukan nilainya maka harus ditentukan terlebih dahulu nilai Reynolds number (Re) spray dan Weber number (We) droplet. Dimana nilai Reynolds number dapat ditentukan menggunakan persamaan :

$$
\begin{aligned}
\operatorname{Re}_{\text {sprayy }}=\frac{\mathrm{v}_{f} d_{n}}{v_{f}} & =\frac{70,24 \mathrm{~m} / \mathrm{s} \times 0,2 \mathrm{~mm}}{55.55 \mathrm{~mm}^{2} / \mathrm{s}} \\
& =252,88
\end{aligned}
$$

Sedangkan nilai Weber number dapat ditentukan menggunakan rumus persamaan :

$$
\begin{aligned}
& W e_{\text {drop }}=\frac{\rho_{f} \mathrm{v}_{l}^{2} d_{n}}{\sigma_{l}} \\
& =\frac{936 \mathrm{~kg} / \mathrm{m}^{3}(70,24 \mathrm{~m} / \mathrm{s})^{2} 0,2 \mathrm{~mm}}{33,4 \mathrm{~N} / \mathrm{m}}=27652
\end{aligned}
$$

Dimana dari data sifat minyak kelapa murni :

$$
\begin{array}{ll}
\sigma_{f} \text { (tegangan permukaan) } & =33,4 \mathrm{~N} / \mathrm{m} \\
\rho_{f} \text { (berat jenis) } & =936 \mathrm{~kg} / \mathrm{m}^{3} \\
\rho_{a} \text { (ro udara) } & =1,2 \mathrm{~kg} / \mathrm{m}^{3} \\
v_{f} \text { (viskositas) } & =55,55 \mathrm{~mm}^{2} / \mathrm{s} \\
v_{f} \text { (kecepatan inject) } & =70,24 \mathrm{~m} / \mathrm{s} \\
d_{n}(\text { Diameter nozzle) } & =0,2 \mathrm{~mm} \\
\mu_{f} \text { (Viscositas dinamis) } & =31 \mathrm{Ns} / \mathrm{m}^{2} \\
\mu_{a} \text { (viskositas udara) } & =0,89 \mathrm{Ns} / \mathrm{m}^{2}
\end{array}
$$

Setelah nilai Reynolds number dan weber number sudah diketahui maka untuk mencari dimensi droplet ialah

$D_{32}$

$$
\begin{aligned}
& =4,12 \\
& \times 0,2 \mathrm{~mm}(252,88)^{0,12}(27652)^{-0,75}\left\{\frac{31 \mathrm{Ns} / \mathrm{m}^{2}}{0.89 \mathrm{Ns} / \mathrm{m}^{2}}\right\}^{0,54} \\
& \left.\qquad \frac{9936 \mathrm{~kg} / \mathrm{m}^{3}}{1,2 \mathrm{~kg} / \mathrm{m}^{3}}\right\}^{0,18}=16,8 \mu \mathrm{m}
\end{aligned}
$$

Sehingga diketahui diameter droplet pada tekanan 50 bar yaitu $16,8 \mu \mathrm{m}$

Pada gambar dibawah ini memperlihatkan panjang nyala api pembakaran minyak kelapa murni dengan beberapa tekanan yakni $50 \mathrm{Bar}, 75$ 
Bar, 100 Bar serta menggunakan diameter lubang nozzle $0,2 \mathrm{~mm}$.

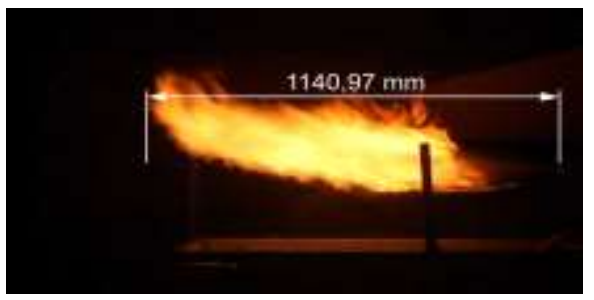

Gambar 6. Panjang nyala api pada tekanan 50 bar

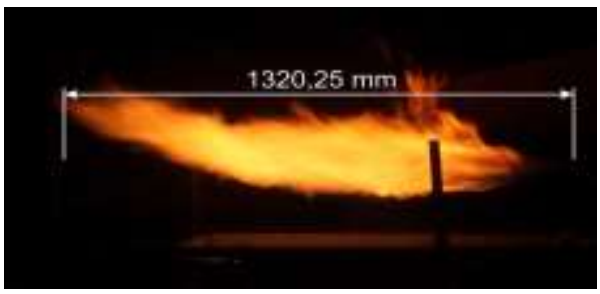

Gambar 7. Panjang nyala api pada tekanan 75 bar

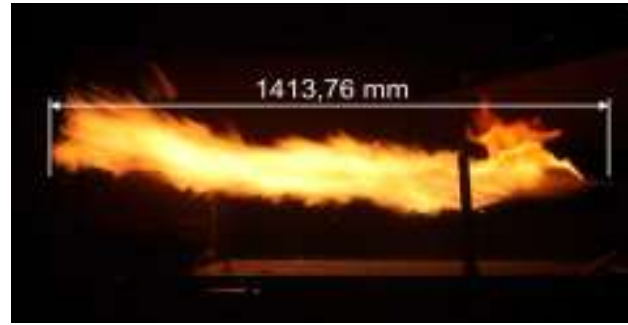

Gambar 8. Panjang nyala api pada tekanan 100 bar

Tabel 5. Panjang nyala api terhadap variasi tekanan

\begin{tabular}{|l|l|l|l|}
\hline No & Tekanan & Nozzel & Panjang \\
\hline 1 & 50 & 0,2 & 1140,97 \\
\hline 2 & 75 & 0,2 & 1320,25 \\
\hline 3 & 100 & 0,2 & 1413,76 \\
\hline
\end{tabular}

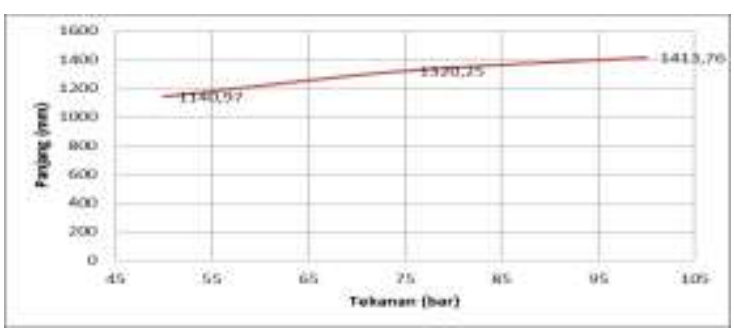

Gambar 9. Grafik panjang nyala api variasi tekanan

Pada gambar 6 grafik dan tabel 5 tersebut terlihat bahwa semakin besar tekanan tehadap nozzel sangat berpengaruh pada nyala api yang di terjadi, bertambahnya panjang nyala api terjadi karena dipengaruhi oleh debit bahan bakar yang melewati lubang nozzel. Dari hasil perhitungan secara teoritis debit bahan bakar paling kecil terdapat pada tekanan sebesar 50 bar dimana debit yang keluar melewati lubang nozzel sebesar 2,177 $\mathrm{m}^{3} / \mathrm{s}$ sedangkan debit paling besar terjadi pada tekanan 100 bar yakni $3,079 \mathrm{~m}^{3} / \mathrm{s}$. Untuk mengetahui nilai debit bahan bakar minyak kelapa pada masing - masing tekanan maka menggunakan rumus persamaan sebagai berikut :

$$
Q=A \cdot v
$$

Dimana luas penampang lubang nozzle $0,2 \mathrm{~mm}$ (A) harus diketahui sebagai berikut :

$$
\begin{aligned}
& A=\frac{\pi}{4} \cdot \mathrm{d}^{2} \\
& A=\frac{3,14}{4} \cdot(0,2)^{2} \\
& A=0,000000031 \mathrm{~m}^{2}
\end{aligned}
$$

Kecepatan semprotan bahan bakar minyak kelapa murni yang diketahui pada tekanan 50 bar yakni :

$$
v_{i}=70,24 \mathrm{~m} / \mathrm{s}
$$

Sehingga nilai debit bahan bakar pada nozzel 0,2 pada tekanan 50 Bar adalah :

$$
\begin{aligned}
Q \quad & =A . v \\
& =0,000000031 \mathrm{~m}^{2} .70,24 \mathrm{~m} / \mathrm{s} \\
& =2,177 \cdot 10^{-6} \mathrm{~m}^{3} / \mathrm{s}
\end{aligned}
$$

Dalam penelitian ini tekanan terhadap nozzle bervariasi dan diameter nozzle yang digunakan tetap. Menurut perhitungan secara teoritis akan terjadi peningkatan debit bahan bakar pada saat tekanan terhadap nozzle diperbesar.

Pada gambar dibawah ini merupakan hasil pengujian flashback nyala api menggunakan minyak kelapa murni dengan variasi tekanan 50 bar, 75 bar dan 100 bar serta diameter nozzle 0,2 $\mathrm{mm}$. Untuk jarak penyalaan awal nyala api divariasikan menjadi 3 jarak diukur dari ujung nozzle yaitu $100 \mathrm{~mm}, 500 \mathrm{~mm}$ dan $900 \mathrm{~mm}$. Berikut merupakan gambar flashback nyala api pada penyalaan awal 100mm dari ujung nozzle dengan beberapa tekanan. 


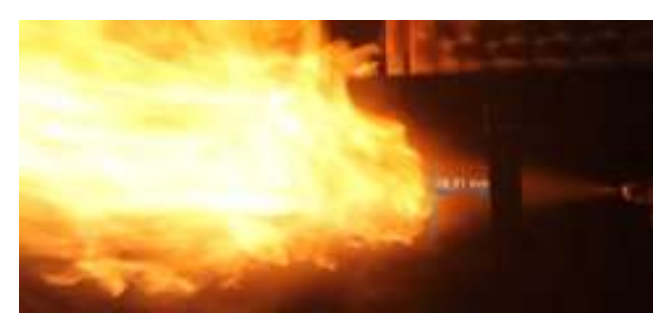

Gambar 10. Flashback nyala api tekanan 50 bar pada penyalaan awal $100 \mathrm{~mm}$

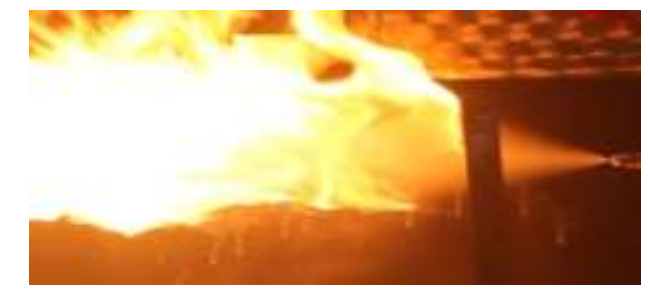

Gambar 11. Flashback nyala api tekanan 75 bar pada penyalaan awal $100 \mathrm{~mm}$

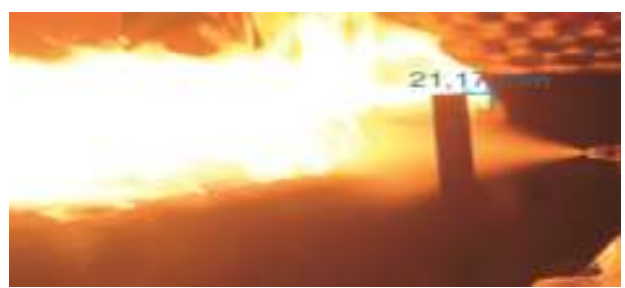

Gambar 12. Flashback nyala api tekanan 100 bar pada penyalaan awal $100 \mathrm{~mm}$

Pada gambar diatas menunjukan bahwa tidak terjadi flashback pada saat pemantik atau sumber nyala api berada pada posisi $100 \mathrm{~mm}$ yang ditandai pada penggaris seperti pada gambar tekanan 50 bar dan 75. Pada tekanan 50 bar nyala api terjadi pada 58,81 $\mathrm{mm}$ dibelakang penggaris, terjadi peningkatan pada saat tekanan diperbesar menjadi 75 bar dimana nyala api menempel pada penggaris. ketika pada saat tekanan dinaikkan kembali ke 100bar baru terjadinya flashback nyala api dengan panjang $21,17 \mathrm{~mm}$.

Kemudian gambar dibawah ini menunjukkan terjadinya flashback nyala api pada tekanan 50 bar, 75 bar dan 100 bar. dengan penyalaan awal $500 \mathrm{~mm}$ dari ujung nozzle.

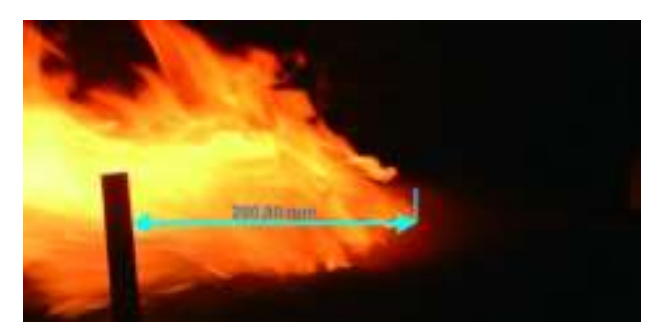

Gambar 13. Flashback nyala api tekanan 50 bar pada penyalaan awal $500 \mathrm{~mm}$

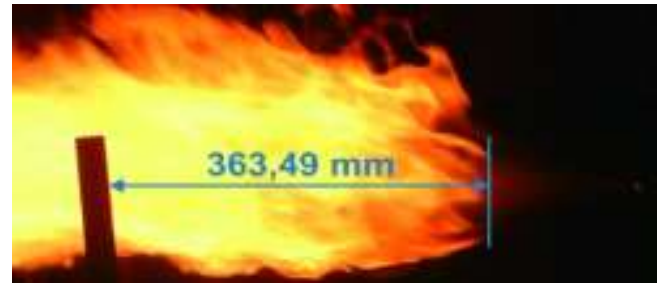

Gambar 14. Flashback nyala api tekanan 75 bar pada penyalaan awal $500 \mathrm{~mm}$

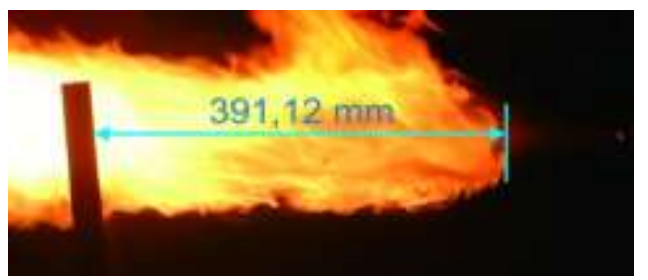

Gambar 15. Flashback nyala api tekanan 100 bar pada penyalaan awal $500 \mathrm{~mm}$

Pada gambar diatas menunjukan bahwa telah terjadi flashback pada saat pemantik api berada pada posisi $500 \mathrm{~mm}$ yang ditandai dengan penggaris seperti pada gambar diatas. Pada tekanan 50 bar nyala api terjadi pada 290,80 mm didepan penggaris, terjadi peningkatan lagi pada saat tekanan terhadap nozzle diperbesar mnjadi 75 bar dimana Panjang nyala api flashback pada tekanan 75 bar meningkat sebesar 72,69 mm. Sedangkan pada saat tekanan dinaikkan kembali menjadi 75 bar ujung nyala api flashback semakin mendekat ke nozzel pada posisi 391,12 mm didepan penggaris. Gambar diatas menunjukkan pada posisi pemantik $500 \mathrm{~mm}$ terjadi flashback yang cukup panjang. Saat tekanan terhadap nozzle sebesar 50 bar terjadi flashback sepanjang 290,80mm semakin tekanan diperbesar terjadi peningkatan yang cukup signifikan. Hal ini menunjukkan bahwa pada posisi $500 \mathrm{~mm}$ di depan penggris bahan bakar sudah berbentuk droplet yang sempurna sehingga dapat terjadi flashback yang cukup panjang.

Gambar dibawah merupakan hasil pengujian flashback nyala api menggunakan minyak kelapa murni pada tekanan 50 bar, 75 bar, dan 100 bar. dengan penyalaan awal $900 \mathrm{~mm}$ dari ujung nozzle.

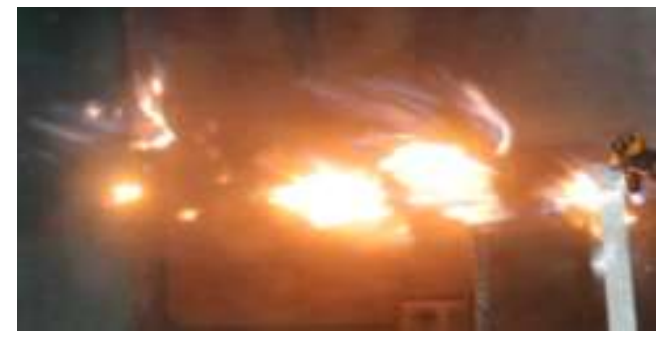

Gambar 16. Flashback nyala api tekanan 50 bar pada penyalaan awal $900 \mathrm{~mm}$ 


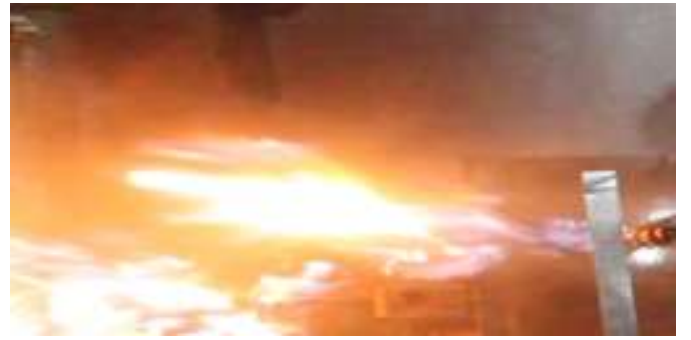

Gambar 17. Flashback nyala api tekanan 75 bar pada penyalaan awal $900 \mathrm{~mm}$

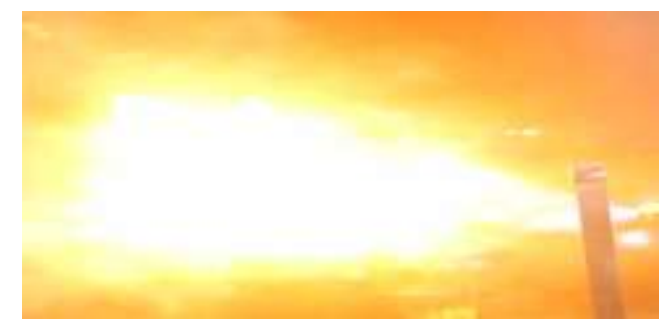

Gambar 18. Flashback nyala api tekanan 100 bar pada penyalaan awal $900 \mathrm{~mm}$

Pada gambar diatas menunjukkan bahwa tidak terjadi nyala api flashback pada posisi pemantik di $900 \mathrm{~mm}$ dari ujung nozzle. Bahan bakar tidak bisa terbakar secara stabil, pada tekanan 50 bar menunjukkan hanya terjadi ledakan kecil saat tekanan dinaikkan lagi terdapat peningkatan nyala api namun tidak sampai terjadi flashback. Nyala api semakin membesar seiring dengan bertambahnya tekanan.

\section{PENUTUP}

Dari hasil penelitian pengaruh variasi tekanan pada pembakaran spray bahan bakar minyak kelapa murni terhadap sudut, panjang nyala api, diameter droplet, flashback nyala api dapat diambil kesimpulan sebagai berikut :

Bahwa variasi tekanan pada nozzle mempengaruhi besar sudut spray, semakin rendah tekanan maka sudut spray semakin kecil dan sebaliknya tekanan tinggi maka sudut spray besar. Sudut yang dihasilkan menggunakan diameter nozzle $0,2 \mathrm{~mm}$ dengan tekanan 50 bar sebesar $40,92^{\circ}, 75$ bar sebesar $42,59^{\circ}$ dan 100 bar sebesar $44,67^{\circ}$. Besar sudut spray paling baik terjadi pada tekanan 100 bar yakni sebesar $44,67^{\circ}$

Semakin tinggi tekanan semakin turun diameter droplet. Pada tekanan 50 bar dimaeter droplet yang didapat sebesar 16,8 micronm, tekanan 75 bar 12,7 micronm, dan tekanan 100 bar sebesar 10 micronm. Diameter paling sempurna ialah terjadi pada tekanan 100 bar yakni 10 micronm semakin kecil droplet membuat pembakaran menjadi sempurna.
Panjang nyala api semakin panjang berbanding lurus dengan besar tekanan. Panjang nyala api yang dihasilkan dari diameter nozzle tetap $0,2 \mathrm{~mm}$ dengan tekanan 50 bar sebesar $1140,97 \mathrm{~mm}$, tekanan 75 bar sebesar $1320,25 \mathrm{~mm}$ dan tekanan 100 bar sebesar 1413,76mm. Panjang nyala api paling bagus dan panjang terjadi pada tekanan 100 bar yakni 1413,76 mm.

Besar tekanan mempengaruhi panjang flashback nyala api di ujung nozzel. Flashback nyala api yang dihasilkan pada jarak penyalaan api $100 \mathrm{~mm}$ tekanan 100 bar sebesar 21,17mm. Jarak penyalaan api $500 \mathrm{~mm}$ dengan tekanan 50 bar sebesar 290,80mm, tekanan 75 bar sebesar $363,49 \mathrm{~mm}$ dan tekanan 100 bar sebesar $391,12 \mathrm{~mm}$. Untuk flashback nyala api yang paling mendekati nozzle terjadi pada penyalaan $500 \mathrm{~mm}$ dengan tekanan 100 bar yakni 391,12mm.

Dalam pengerjaan Penelitian ini kami yakin masih banyak kekurangan sehingga perlu adanya penyempurnaan lanjutan pada alat pengujian. Beberapa saran yang perlu diperhatikan untuk dapat mencapai hasil yang lebih baik antara lain :

Perlu dilakukan pada ruangan khusus (tertutup) pada saat proses pengujian maupun pengambilan data.

Untuk aspek keamanan pada saat pengujian perlu dilakukan agar mencegah hal yang tidak diingkan.

Alat pengujian masih perlu disempurnakan karena masih banyak kekurangan.

\section{Ucapan Terima Kasih}

Ucapan terima kasih kepada seluruh Dosen Umaha, Khususnya Dosen Teknik Mesin ( Bapak Dony perdana ST., MT. ) atas bimbingan dan saran diberikan sehingga Saya dapat menyelesaikan penelitian ini tepat waktu. Serta TEAM SPRAY COMBUSTION dan keluarga atas dukungannya.

\section{DAFTAR PUSTAKA}

Adam, A., Rizalman, M., \& Yatsufusa, T. (2015). Analysis of Diesel Spray Droplets Behavior Using Shadowgraph Technique Images. International Journal of Materials, Mechanics and Manufacturing, 3(1), 60-64. https://doi.org/10.7763/ijmmm.2015.v3. 167

Afifah, Y. N. (2016). ALIRAN TAK TUNAK FLUIDA NANO MAGNETOHIDRODINAMIK ( MHD) YANG MELEWATI BOLA. 
Afifah, Y. N. (2019). (2019). Analysis of Unsteady Magneto Hydro Dynamic ( MHD ) Nano Fluid Flow Past A Sliced Sphere Analysis of Unsteady Magneto Hydro Dynamic ( MHD ) Nano Fluid Flow Past A Sliced Sphere. IOP Conference Series: Materials Science and Engineering, 494, 012033. https://doi.org/10.1088/1757899X/494/1/012033

Afifah, Y. N., \& Putra, B. C. (2018). Model Matematika Aliran Tak Tunak Pada Nano Fluid Melewati Bola Teriris Dengan Pengaruh Medan Magnet. Teknika: Engineering and Sains Journal, 2(2), 119124.

Deshmukh, D., Madan Mohan, A., Anand, T. N. C., \& Ravikrishna, R. V. (2012). Spray characterization of straight vegetable oils at high injection pressures. Fuel, 97(July), 879-883.

https://doi.org/10.1016/j.fuel.2012.01.0 78

Equipment, E. (2013). Concept and Theory Training. 24-25.

Ergianto, M. D., Ghurri, A., Gede, I. D., \& Swastika, P. (2018). Pengaruh Tekanan Injeksi terhadap Tingkat Atomisasi dan Karakteristik Spray pada Airblast Atomizer. 7(4), 312-315.

I Wayan Suma Wibawa, Kusuma, I. G. B. W., \& Budiarsa, I. N. (2015). Uji Variasi Tekanan Nosel Terhadap Karakteristik Semprotan Bahan Bakar Biodiesel. 1(2), 35-44.

Indonesia, U., Mahandari, C. P., Teknik, F., Pasca, P., \& Teknik, S. (2010). FENOMENA FLAME LIFT-UP FENOMENA FLAME LIFT-UP.

Juniarta, I. K., Wirawan, I. K. G., \& Ghurri, A. (2017). Studi Eksperimental Pengaruh Variasi Tekanan Terhadap Sudut Semburan Minyak Jelantah. 6(2), 2-6.

K, J. C. (2006). Pengaruh Variasi Persentase Minyak Kelapa Pada Bahan Bakar Solar Terhadap Intermittensi Api Pembakaran.

Novilla, A., Nursidika, P., \& Mahargyani, W. (2017). Komposisi Asam Lemak Minyak Kelapa Murni (Virgin Coconut Oil) yang Berpotensi sebagai Anti Kandidiasis. EduChemia (Jurnal Kimia Dan Pendidikan), 2(2),

161. https://doi.org/10.30870/educhemia.v2i 2.1447

Sánchez, A. L., Urzay, J., \& Liñán, A. (2015). The role of separation of scales in the description of spray combustion. Proceedings of the Combustion Institute, 35(2),

1549-1577. https://doi.org/10.1016/j.proci.2014.08. 018
Sasongko, M. N. (2018). Pengaruh Prosentase Minyak Goreng Bekas Terhadap Karakteristik Pembakaran Droplet Biodiesel. IV(2).

Shafaee, M., Banitabaei, S. A., Ashjaee, M., \& Esfahanian, V. (2011). Effect of flow conditions on spray cone angle of a twofluid atomizer. Journal of Mechanical Science and Technology, 25(2), 365-369. https://doi.org/10.1007/s12206-0101215-5

Yunita Nur Afifah, MNH Qomarudin, \& Imamatul Ummah. (2020). Optimal Control Model Pemanenan Prey-Predator di Area Konservasi Ikan. Buana Matematika: Jurnal Ilmiah Matematika Dan Pendidikan Matematika, 10(1), 1-16. https://doi.org/10.36456/buanamatemat ika.v10i1.2410

Zulfadli, T. (2018). Kajian Sistem Pengolahan Minyak Kelapa Murni (Virgin Coconut Oil) dengan Metode Pemanasan. International Journal of Natural Sciences and Engineering, 2(1), 34-41. 